Я. Кравчук, Ю. Зінько. Вивчення Степаном Рудницьким...

ISSN 2519-2620. Проблеми геоморфології і палеогеографії...2019. Вип. 1 (9), 3-20

УДК 551.4-057.4(477.43/.44)(091); DOI 10.30970/gpc.2019.1.2796

ВИВЧЕННЯ СТЕПАНОМ РУДНИЦЬКИМ МОРФОЛОГІЇ, ГЕНЕЗИСУ ТА ІСТОРІЇ РОЗВИТКУ РЕЛЬЕФУ ПОДІЛЛЯ

Ярослав Кравчук, Юрій Зінько

Львівський національний університет імені Івана Франка,

yaroslavkravchuk@ukr.net;

zinkoyuriy@gmail.com; https://orcid.org/0000-0001-5546-6308

Анотація. Вивчення морфології генезису та історії розвитку рельєфу карпатського і передкарпатського басейнів Дністра С. Рудницьким продовжено на Поділлі. Підсумком багаторічних експедиційних досліджень (1903-1912) стала монографія "Знадоби до морфології подільського сточища Дністра", рекомендована до друку на засіданні математично-природописної секції НТШ 17 квітня 1912 року.

У цій праці, крім детальної морфографічної і морфометричної характеристики рельєфу галицького Поділля, велика увага приділена формуванню річкової мережі басейну Дністра, геологічній будові, палеогеоморфології та морфологічно-генетичним проблемам.

При вивченні подільського басейну Дністра С. Рудницький зробив численні висновки 3 проблем морфологічної регіоналізації, історії розвитку рельєфу (зокрема формування долини Дністра та його подільських приток), які й досі не втратили актуальності. Серед основних результатів дослідження С. Рудницьким морфогенезу та еволюції рельєфу подільського басейну Дністра необхідно виокремити такі: 1. Геоморфологічний поділ галицького Поділля з виокремленням районів: Розточчя, Верещицько-Щирецьке пониззя, Миколаївсько-Бобрецька горбовина (Підопілля), Опільська горбовина, Подністря, власне Поділля та Гологоро-Кременецьке пасмо. 2. Уточнення історії розвитку окремих районів: ератичний скандинавський матеріал на Розточчі мішаний (скандинавсько-карпатський) та відкладений флювіагляціальними потоками i поширений до висот 380 м. 3.У перигляціальний плейстоценовий період майже усі піски основних районів були охоплені еоловими процесами. 4. Підтверджено запропонований В. Тессейром геологічний поділ Поділля на західне і східне з виокремленням п'яти морфологічних смуг. 5. Обгрунтовано морфотектонічну схему розвитку Поділля, пов'язану 3 тектонічними підняттями Гологоро-Кременецького пасма, яке спричинило нинішній нахил Подільської височини до південного сходу-сходу. 6. Зазначено, що тектонічні лінії Бердо-Нароль і КовалівкаСмиківці характеризують палеозойську плиту Поділля як типовий тектонічний горст. 7. Детально описано старі рінища (алювіальні відклади) Дністра з присутнім карпатським матеріалом на Подністрі, Опіллі і власне Поділлі, що поширені смугою на віддалі 1420 км від сучасного русла Дністра. 8. На основі літературних джерел і власних досліджень зроблено висновок, що всюди на старих рінищах, пісках і алювіальних глинах лежить “еолічний" лес. 9. Стверджено, що старі наддністрянські рінища не можуть бути старшими від поверхонь вирівнювання Карпат i Передкарпаття. 10. Доведено формування долинної мережі Дністра у пліоцені та плейстоцені, що визначило напрям течій лівих приток і перехоплення їхніх верхів 'їв витоками Західного Бугу.

Загалом необхідно зазначити, що С. Рудницькому в “Знадобах до морфології подільського сточища Дністра" вперше в тогочасній геоморфологічній літературі вдалось реалізувати комплексний морфогенетичний підхід до вивчення рельєфу регіону: від стандартизованих морфологічних описів через систематизацію морфологічної структури регіону до історико-генетичної інтерпретації головних рис морфології рельєфу.

(с) Кравчук Ярослав, Зінько Юрій, 2019. 
Я. Кравчук, Ю. Зінько. Вивчення Степаном Рудницьким...

ISSN 2519-2620. Проблеми геоморфології і палеогеографії...2019. Вип. 1 (9), 3-20

Ключові слова: морфологічні райони; сточище (басейн) Дністра; старі наддністрянські рінища (алювіальні відклади); гляціальний ератичний матеріал; флювіогляціальні відклади; блукаючі і врізані меандри; горбовина; Поділля.

\section{STEPAN RUDNITSKY'S STUDIES OF THE PODILLYA RELIEF: ITS MORPHOLOGY, GENESIS AND HISTORY OF DEVELOPMENT}

Yaroslav Kravchuk, Yuriy Zinko,

Ivan Franko National University of L'viv

Abstract. S. Rudnitsky's research continued in Podillya; he went on studying the morphology of genesis and history of the relief of the Carpathian and pre-Carpathian Dniester basins. Many years of expeditionary research (1903-1912) resulted in the monograph "Prerequisites for Studying Morphology of the Podilsky Catchment Area of the Dniester", which was recommended for publication at the meeting of the Mathematical \& Nature Descriptive section of the Shevchenko Scientific society (NTSh) on April 17, 1912.

This work provides detailed morphographic and morphometric characteristics of the Galician Podillya relief. The monograph also reports on the formation of the Dniester basin river system, geological structure, paleogeomorphology, as well as morphological \& genetic problems.

In studying the Podilsky Dniester Basin, S. Rudnytsky made numerous conclusions on the problems of morphological regionalization, the relief history, in particular the formation of the Dniester valley and its Podilsky tributaries, which have not lost their relevance to this day. We can distinguish the following major points among the main findings of S. Rudnitsky's research of morphogenesis and the evolution of the Podilsky Dniester basin relief:

(1) Geomorphological division of the Galician Podillya with districts allocation: Roztochya, Vereshchytsky-Shchyrets lowland, Mykolayiv-Bobretskyi "horbovyna" (land surface with hills) (Pidopillya), Opilsky "horbovyna", Podnistriya, Podillya and GogoloroKremenetsk Ridge; (2) Clarification of the history of individual regions development: the erratic Scandinavian material in Roztochya is mixed (Scandinavian-Carpathian); it is deposited by fluvia-glacial flows and represented up to altitudes of $380 \mathrm{~m}$; (3) In the periglacial Pleistocene period, almost all the sands of the main areas had eolian processes; (4) Confirmation of the Podillya geological division into western and eastern with five morphological bands, proposed by W. Teisseyre; (5) Justification of the morphotectonic scheme of Podillya development, connected with tectonic elevations of the Hologoro-Kremenets Ridge, which caused the current inclination of the Podolsk hills to Southeast-East; (6) Statement that the tectonic lines of Berdo-Nârul and Kovalivka-Smykivtsi characterize the Paleozoic Platform of Podillya as a typical tectonic horst; (7) Detailed description of the Dniester "rinyshcha" (alluvial deposits) with the Carpathian material present in Podniester, Opil and Podillya itself, which are present as a strip at a distance of 14-20 km from the modern Dniester river bed; (8) Based on literary sources and his own research, the scientist came to the conclusion that there is "eolian" loess in the "rinyshcha", sands and alluvial clay; (9) It is argued that the old Nadnistryan rivers cannot be older than the planation surfaces of the Carpathians and PreCarpathians; (10) Formation of the Dniester valley pattern in Pliocene and Pleistocene, which determined the direction of the flows of the left tributaries and their capture by the Western (Zakhidny) Bug river sources.

Finally, in his "Prerequisites for Studying Morphology of the Podilsky Catchment Area of the Dniester" S. Rudnitsky managed to use a complex morphogenetic approach to studying the region relief for the first time geomorphological literature: from standardized morphological descriptions through systematization of the morphological structure of the region to the historical genetic interpretation of the main features of relief morphology.

Key words: morphological districts; Dniester catchment area (basin); Naddnistriansky "rinyshcha" (alluvial deposits); glacial erratic material; fluvia-glacial deposits; free and 
entrenched meanders; "horbovyna" (land surface with hills); Podillya.

Вступ. Праця Степана Рудницького "Знадоби до морфології подільського сточища Дністра" надрукована у збірнику математично-природничої секції НТШ 1913 р. У вступі автор зазначив, що експедиційні дослідження галицького Поділля розпочали 1903 р. 3 північно-східної частини (Тернопільщина, Теребовлянщина, Збаражчина); влітку і восени 1905 р. - частина Пониззя і Подністря (Щиреччина, Комарнянщина, околиці Галича); весна і літо 1906 р. східне Опілля і наддністрянське Поділля (Рогатинщина, південна Бережанщина, Товмачина, Монастирищина, Бучаччина; восени 1906 р. - Миколаївщина i Бібречина); влітку 1907 р. - Зборівщина, Золочівщина, північна Бережанщина, Підгаєчина; влітку 1908 р. - дністрянське Розточчя і західне Опілля. Упродовж 1909-1911 pp. автор досліджував наддністрянські околиці між Нижневом і Заліщиками та Борщівщину і Заліщиччину із залученням слухачів географії Львівського університету. Автор планував провести дослідження й у східній частині басейну Дністра, однак не отримав дозволу, отож обмежив публікацію тільки галицьким Поділлям.

\section{1. Методологічні підходи і методика аналізу рельєфу Поділля у дослідженнях С. Рудницького}

У геоморфологічних працях Степан Рудницький широко використовував морфологічний, генетичний та еволюційний підходи до вивчення рельєфу. Серед цих методів за базовий слугував морфологічний аналіз, яким С. Рудницький прекрасно володів та вдосконалював 3 кожним новим геоморфологічним дослідженням. Йому належать детальні морфологічні описи рельєфу окремих регіонів Західної України (Карпати, Передкарпаття, Закарпаття, Поділля) та усієї Східної Європи (Рудницький, 1926). Загалом, 3 точки зору вчення про морфологію рельєфу, С. Рудницький у своїх “морфологічних знадобах" реалізував вивчення складових частин земної поверхні та їхніх взаємних просторових співвідношень (морфологічної структури). Склад і структура земної поверхні у його дослідженнях слугували необхідною основою для генетичних, історичних, динамічних інтерпретацій рельєфу (Зінько, 1994, с. 93-94).

Дослідженню рельєфу Поділля хронологічно передували регіональні праці щодо карпатського і передкарпатського сточища (басейну) Дністра (Рудницький, 1905, 1907). У цих працях морфологічні описи виглядають, здебільшого, як інвентаризаційні, їх важко використати для історико-генетичних інтерпретацій рельєфу. Проте у подільських дослідженнях морфологічний підхід більшою мірою систематизований, спрямований на виявлення певних закономірностей у структурі і розвитку поверхні регіону. Ці закономірності у морфології рельєфу слугували основою для трактування С. Рудницьким певних морфогенетичних проблем Поділля: еволюції долинної мережі, розвитку основних його геоморфологічних районів. Морфологічний аналіз у цьому дослідженні виконував певні функції під час вивчення рельєфу регіону: параметричну, систематизаційну та індикативно-еволюційну (Зінько, 1994).

У “Знадобах до морфології подільського сточища Дністра" морфологічні описи терену займають чільне місце. Детально описано морфологію рельєфу кожного з подільських районів (Розточчя, Пониззя, Підопілля, Опілля, Подністря, власне Поділля). Основою для морфологічних описів слугують 
картографічні матеріали та польові дослідження. Останні, як зазначав С. Рудницький, $\epsilon$ найважливішою частиною кожної природоописної розвідки. Морфологічний аналіз рельєфу подільських районів органічно охоплював вивчення складових частин земної поверхні та їхніх просторових поєднань.

При здійсненні морфологічного аналізу рельєфу основними об'єктами дослідження обрано домінуючі додатні та від'ємні форми рельєфу, які розглядали в межах основних таксонів (районів) Поділля. За С. Рудницьким, на Поділлі додатні форми представлені горбами, лавами, валами, грядами, плитами, а від'ємні - долинами, суходолами, долинищами, заглубинами. Особливості їхньої морфології деталізують завдяки таким елементам: верхні (вершинні) поверхні, ребра (гребеневі лініі), збоча (привершинні схили) у додатних формах; днища, береги (придолинні схили), меандри - у від'ємних. Такий поділ морфології домінуючих форм височини дав змогу представити іiі будову у вертикальному розрізі з виокремленням “верхів" та “низів” рельєфу.

Важливою характеристикою для домінуючих форм рельєфу С. Рудницький вважав планову орієнтацію та конфігурацію форм, що представляють рельєф у горизонтальному (латеральному) розрізі. Зокрема, лінійні форми рельєфу визначали за їхньою орієнтацією щодо сторін горизонту. На Поділлі переважаючими у формі є субмеридіональні (Пн-Пн-3х), субширотні (3x-Пн$3 \mathrm{x})$, ускісні (Пн-3x) та меридіональні (Пн-Пд) напрями. Рудницький значну увагу звертав на залежність морфології долин від напряму їхньої орієнтації. Цю залежність учений використав для морфохронологічної інтерпретації еволюції долинної сітки подільського сточища Дністра.

Важливою в морфологічному аналізі регіону він вважав кількісну оцінку (параметризацію) форм та елементів рельєфу. Серед параметрів, що використовував найчастіше, - абсолютна висота (вершин, днищ), відносна висота (горбів, валів), крутість схилів, похил і ширина днищ. Ці морфометричні показники разом 3 детальними морфографічними рисами дали змогу С. Рудницькому детальніше представити морфологічну картину кожного 3 подільських районів.

Зокрема, С. Рудницький детально вивчав на Поділлі особливості морфології домінуючих форм у поперечному та поздовжньому профілях і з'ясував, що грядово-долинні форми Поділля відзначаються асиметричною будовою в поперечному профілі щодо вододільних та тальвегових ліній (білатеральний вид симетрії): вона проявляється для вершинних та схилових елементів. Асиметрія верхніх грядових та горбистих форм представлена у відмінностях висоти іiі крайових частин. Асиметрія схилів проявляється у відмінностях показників крутості, довжини та ступеня розчленування схилів у поперечному профілі форм. За Рудницьким, для Поділля характерні прояви закономірної асиметрії, де крутішими й коротшими є схили західної та південно-західної експозиції, а похилішими та розчленованими - схили східної та північно-східної експозиції. Ця асиметрія проявлена насамперед у формах меридіональної та ускісної орієнтації. Наголошено на ярусній узгодженості асиметрії, що виражена як для вододільних, так і для долинних форм. Меандрам меридіональних рік Поділля основних притоків Дністра - властивий перемінний вид асиметрії 3 експозиційною зміною місцеположення крутого борта долини.

У праці “Знадоби до морфології подільського сточища Дністра" 
С. Рудницький всебічно проаналізував морфологічну структуру рельєфу просторове взаємовідношення між складовими частинами земної поверхні певної території. Морфологічну структуру вивчено як для окремих районів (мікроструктура), так і для Подільського регіону загалом (мезоструктура). Детально висвітлено такі аспекти морфологічної структури основних подільських районів: 1) співвідношення між додатними та від'ємними формами; 2) поєднання домінуючих орієнтацій форм; 3) визначення характерного малюнка (текстури) району загалом.

Досліджуючи Поділля, С. Рудницький зазначав, що “морфологічна характеристика ... мусить узгляднювати морфологію височинних верхів і морфологію долин і допори комбінуючи характерні прикмети обох груп форм поземелля доходити до позитивних клясифікаційних вислідів” (Рудницький, 1913). Згідно з таким підходом, райони Поділля поділили залежно від співвідношення додатних і від'ємних форм. До районів з перевагою горбовиннопластових форм зачислено Розточчя, горбовинних форм - Підопілля та Опілля, горбовинно-лавкових форм - Пониззя і Подністря, а власне Поділля належить до територій $з$ домінуванням плитових поверхонь. Згадані домінуючі форми у кожному 3 районів поєднуються 3 субдомінантними, утворюючи своєрідні поєднання вододільних і долинних форм: горбовинно-долинні, улоговинногорбовинні, розчленованого плато.

Детальне вивчення складу і структури поверхні Поділля слугувало основою для вирішення С. Рудницьким певних морфогенетичних проблем. За такого підходу морфологія рельєфу відіграє роль індикатора основних рельєфотворчих процесів та етапності становлення поверхні.

Найповніше морфохронологічний підхід застосований С. Рудницьким для 3'ясування етапності розвитку долинної мережі басейну Дністра. Аналізуючи долинні форми Поділля, вчений встановив, що домінуючі ускісні й меридіональні долини відрізняються одна від одної порядком і морфологічними особливостями. Ускісні долини відповідають низькопорядковим водотокам i характеризуються зрілістю форм, а меридіональні долини представлені високопорядковими водотоками (основні притоки Дністра) і мають омолоджений вигляд. Ці особливості морфологічної структури подільських долин дали змогу Рудницькому обгрунтувати таку схему хронології їхнього розвитку: на першому етапі (пліоценському) формувались долини ускісного напряму, на другому (четвертинний час) - меридіональні долини (Зінько, 1994).

Загалом реалізований С. Рудницьким морфохронологічний підхід до еволюції рельєфу дав змогу визнати суттєву роль тектонічного фактора у формуванні морфологічної структури Поділля. У генетичному аспекті вчений одним 3 перших здійснив на Поділлі морфотектонічний аналіз (від рельєфу до тектоніки), доповнюючи тектоморфогенні побудови (від тектоніки до рельєфу) В. Тессейра. 3 морфотектонічних позицій слід було чекати пояснення “законної” асиметрії подільських форм, що не вдалось реалізувати автору в “Знадобах до морфології подільського сточища Дністра".

Отже, необхідно зазначити, що С. Рудницькому в “Знадобах до морфології подільського сточища Дністра” вперше у тогочасній геоморфологічній літературі вдалось реалізувати комплексний морфогенетичний підхід до вивчення рельєфу регіону: від стандартизованих морфологічних описів через систематизацію 
морфологічної структури регіону до історико-генетичної інтерпретації головних рис морфології рельєфу.

2. Аналіз морфології, генетичних і вікових особливостей рельєфу та будови покривних відкладів Поділля.

Морфологія і генетико-еволюиійні особливості основних регіонів Поділля. Морфологічні, генетичні та еволюційні властивості рельєфу галицького Поділля дослідник розглядає для основних геоморфологічних районів (окремі частини за Рудницьким, 1913). За регіональним принципом побудована структура роботи: Розточчя, Верещицько-Щирецьке пониззя, Головний Європейський вододіл на Розточчі і Пониззі та на Опіллі і Поділлі, Миколаївсько-Бобрецька горбовина (Підопілля), Опільська горбовина, Подністря, Поділля, долини Поділля. Кожен регіон автор супроводжує детальною морфологічною та геологічною характеристиками. Зокрема, значну увагу приділяє тектоніці і палеоморфології, старим наддністрянським рінищам та іншим ділювіальним (плейстоценовим - $Я$. $K$.) відкладам Поділля, а також морфологічно-генетичним проблемам.

Розточчя. Досить детально у межах Розточчя С. Рудницький характеризує ділювіальні (плейстоценові) відклади, зокрема гляціальний ератичний матеріал. Згадуючи широко відомі того часу праці професора М. Ломніцького, С. Рудницький зазначає, що “в тутешнім сточищі Дністра немає ні сліду правдивих морен” (Рудницький, 1907, с. 23). Змішані карпатські та скандинавські відклади С. Рудницький детально проаналізував у праці, присвяченій морфології підкарпатського сточища Дністра (1907) і дійшов висновку, що відбувалося змішування відкладів ріками 3 півночі і півдня під час наступу і відступу льодовика.

Значну увагу в межах дністерського Розточчя С. Рудницький також приділив північному гляціальному матеріалу. "Найчастіше гляціальний матеріал зустрічається на вододілі від Гарая до Ділової гори (за М. Ломніцьким) північніше від Милятина, Озірної, на захід від Королевої гори... Найбільше мені знаний поклад гляціального матеріалу є на Поповій горі... при дорозі, що йде 3 Озірної до Верещиці. Я бачив тут кілька брусів майже півметрового проміру, переважно гранітових і сієнітових" (Рудницький, 1912).

3 посиланням на М. Ломніцького, С. Рудницький зазначає, що ератичний матеріал на території Розточчя трапляється до висот 380 м. У дністровій частині Розточчя (верхів'я Верещиці) ератики також присутні на дещо менших висотах поблизу Гарая, Чорного горба, Ділової та Кам'яної гори. На найвищих горбах Гарая (396 м), Вівсяної гори (387 м) та інших не знайдено північного матеріалу, “однак при малій різниці висот від інших місць, де цей матеріал густо розкинений... не можна аподиктично заперечити, неначе б гляціального матеріалу на тих найвищих точках тутешнього Розточчя не було зовсім" (Рудницький, 1912, с. 27).

Також С. Рудницький наголошує, що високе положення гляціального матеріалу нагадує обставини, що панують між Перемишлем і Самбором недалеко від краю Карпат. Як висновок - “тутешні ділювіальні рінища є так само мішані як ближчих околиць” (Рудницький, 1912, с. 27), відкладені флювіогляціальними потоками.

Найпоширенішими у дністерській частині басейну плейстоценовими відкладами є піски: у долині Верещиці аж до Страдецького пролому, у долинах 
Добросинського потоку і Старої ріки, а також на схилах долин.

Твердження М. Ломніцького про те, що ці піски є результатом розмиву пліоценових пісків з домішками зерняток гляціального матеріалу, С. Рудницький заперечив. Відсутні у них також будь-які прикмети, що вони є моренними. Натомість у них наявні всі ознаки того, що вони відкладені текучими водами.

У межах дністерського Розточчя С. Рудницьким досліджені також піски еолового походження. Він вважав, що у степово-пустельній лесовій добі майже всі плейстоценові піски були охоплені дефляційними процесами. Ділянки 3 колишніми дюнами трапляються навіть у лісових масивах. Орієнтація ділянок постійних і дефляційних пісків доволі виразно простежується 3 Пн3х-3x та ПдСx-Cx, тобто в напрямі найстаріших долинних систем Розточчя. На південь від лінії Добростани-Карачинів-Львів і прилеглі Мальчицька і РудненськоБілогорська улоговини та ділянки долини Верещиці чітко окреслюють південну межу Розточчя (за М. Рудницьким).

Південніше розміщене Верещицько-Щирецьке пониззя, південна межа якого на півдні проходить уздовж Дністра, на заході - Головним Європейським вододілом, на сході (Підопілля) межа проходить від Рудно на Оброшиного, Глинну, Пустомити, Милошевичі, Хоросно, попри Красів, Бродки, Демню і Миколаїв - до долини Дністра. Характерними особливостями рельєфу цього регіону С. Рудницький вважав значно нижчі абсолютні і відносні висоти та невелику різницю між ними. Абсолютні висоти зрідка перевищують $300 \mathrm{~m}$, поздовжньо-овальні підвищення і плоскодонні пониження мають переважний напрям Пн3x-ПдСx, що часто наближається навіть до $3 \mathrm{x}-\mathrm{Cx}$. Загалом територію цього регіону морфографічно можна зачислити до пенепленізованих.

Ще однією характерною ознакою цього регіону (за С. Рудницьким) є велика кількість тарілко- і лійкоподібних заглибин, що дало йому підстави після аналізу геологічної будови вважати їх красовими (карстовими - Я. К.) явищами.

В українській літературі виокремлений С. Рудницьким регіон ВерещицькоЩирецького пониззя переважно зачисляли до Львівського плато (Цись, 1972) і Львівського Опілля (Геренчук, 1972).

Під час аналізу геологічної будови зазначеного С. Рудницьким Пониззя автор значну увагу приділив ділювіальним (плейстоценовим) відкладам. Зокрема, гляціальний матеріал представлений тут доволі часто (подано за М. Ломніцьким), його східна межа простягається вздовж східного берега Верещиці від Цунева до Малкович. "Більше цього матеріалу подибуємо на східнім березі Дроздовицького ставу на причілку гряди 323 м. Серед ділювіальних пісків знаходимо тут старокристальне рінище, зложене 3 гранітів, амфіболітів і дальських пісковиків. Поодинокі лобяки доходять величини пястука... Більші лобяки гляціального матеріалу знайшов М. Ломніцький в

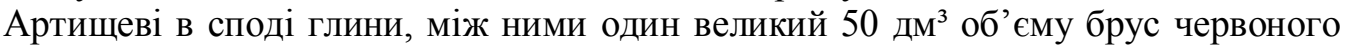
граніту. Так само в споді ділювіальної глини в Малковичах находив він лобяки 3 граніту, гнейса та амфіболіта"(Рудницький, 1913, с. 46).

Виокремлений С. Рудницьким невеликий природний район МиколаївськоБобрецька горбовина розміщений між Розточчям на півночі, долиною Дністра на півдні, долиною Боберки на сході і долиною (місцями басейном) Щирки на заході. Щодо цього масиву С. Рудницький звернув увагу на те, що він $\epsilon$ прямим продовженням Розточчя на південний схід до Дністра і Боберки. Ламана лінія 
Я. Кравчук, Ю. Зінько. Вивчення Степаном Рудницьким..

10

ISSN 2519-2620. Проблеми геоморфології і палеогеографії...2019. Вип. 1 (9), 3-20

через Милошевичі-Поршну-Кугаїв-Вовків-Товщів-Черепин ділять горбовину на дві частини: північну (напрям повністю збігається з Розточчям) і південну (напрям близький до південного). Тоді ще не було відомо, що Розточчя $\mathrm{i}$ Миколаївсько-Бобрецька горбовина сформовані на південно-східних тектонічних виступах Західноєвропейської платформи (Рава-Руський і Розтоцький).

Звернув увагу С. Рудницький і на абсолютні висоти обох частин: північна значно нижча - усереднена висота 335 м (поблизу Поршни - 344 м, Сокільник 348 м, Пасік Зубрицьких - 350 м, Липників - 360 м і тільки неподалік від Пасік і Сихова - 388 і 367 м); південна частина з усередненою висотою 380 м, багато вершин висотою понад 400 м.

Північна частина з мілко заглибленими долинами, південна частина сильно i глибоко розчленована мальовничими долинами, великою кількістю дрібних долинок, суходолами i яругами. Автор дає детальну морфометричну характеристику всім основним долинам та їхніми притокам.

Миколаївсько-Бобрецька горбовина творить перехід від Розточчя i Верещицько-Щирецького пониззя до східної частини Подільської височини, що носить здавна назву Опілля (Рудницький, 1913, с. 54). Через це він називає Миколаївсько-Бобрецьку горбовину Підопільською.

Опільська горбовина (Рудницький, 1913, с. 64) має вигляд неправильного трикутника, опертого одним боком у північний рубець Поділля; другий його бік творить лінія від Золочева до гирла Стрипи, яка проходить вододілами між Золотою Липою і Стрипою, Золотою Липою і Коропцем, а від Підгаєць - до гирла Стрипи. Третій бік йде долиною Дністра від гирла Стрипи до гирла Золотої Липи, а звідти - попри Горожанку, Липицю, Пуків, Рогатин, Підкамінь, Стрілиська, Баківці та Дев’ятники - до долини Боберки.

Зокрема, С. Рудницький пояснює, чому в географію Поділля вводить поняття “опільської горбовини”. Назва Опілля здавна вживана і прийнята в народі, зокрема i на Перемишлянщині, Рогатинщині, Поморянщині, Бережанщині. Менше ця назва підходить для Підгаєччини і Монастирищини, де назви Опілля не вживають. "Однак оправдує мене при розтягнені цієї назви на південний схід потреба ... для одноцільної морфологічної області, а потім обставина, що лиш західні частини Монастирищини і Підгаєччини втягнені мною в опільську область”(Рудницький, 1913, с. 64).

Як зазначає С. Рудницький, Опілля на перший погляд $\epsilon$ безладною горбовиною, розчленованою долинами Боберки, Свіржа, Гнилої Липи, Нараївки, Бибельки, Золотої Липи та їхніми численними притоками. Долини другого і третього порядків різних напрямів течій є переважно глибокими та вузькими. Головні ріки мають напрям, близький до меридіонального, порівняно широкі забагнені долини.

На відміну від Верещицько-Щирецького пониззя і Миколаївсько-Бобрецької горбовини, на Опіллі зрідка трапляються вирівняні ділянки, які з'являються у східній частині і творять перехід від Опілля до власне Поділля. Опільську горбовину С. Рудницький поділяє на дві частини: західну і східну.

Західна частина прилягає 3 півночі і північного заходу до найвищої ділянки Головного Європейського вододілу (Камула, 471 м; Замчисько, 458 м), звідки поступово понижується на Пд-ПдСх. У межах цієї частини С. Рудницький виокремлює безліч горбовинних лав (пасм) різної ширини, довжини і висоти. Усі 
Я. Кравчук, Ю. Зінько. Вивчення Степаном Рудницьким..

11

ISSN 2519-2620. Проблеми геоморфології і палеогеографії...2019. Вип. 1 (9), 3-20

ці пасма мають переважний напрям 3 північного заходу на південний схід 3 незначними відхиленнями.

Східну частину Опільської горбовини С. Рудницький виокремлює на схід від долини Гнилої Липи, яка довгою неправильною смугою простягається на південь і південний схід. Східну межу творить лінія, яка відокремлює горбовинний простір від чисто “плитового”. Східне Опілля, за С. Рудницьким, “це горбовина 3 неспокійним профілем і дуже незначними рівними просторами ... чим далі на схід і південний схід розчленування первісної плити ерозією є слабке і щораз то більше зовсім не нарушених або мало що нарушених просторів лежить серед виробленої горбовини" (Рудницький, 1913, с. 72).

Максимальні абсолютні висоти засвідчують загальне пониження Східного Опілля з ПнЗх на ПдСх, однак, як зазначає С. Рудницький, воно є незначним. При цьому автор розрізняє дві частини - одна межує з Головним Європейським вододілом, а інша розташована на захід і південний захід від Бережан.

Поділ С. Рудницького Опілля на західне і східне добре пов'язується 3 геологічною будовою. Для Західного Опілля і Підопілля найстарішими відкладами є крейдові, для Східного - девонські та юрські. Для обох частин четвертинні відклади представлені глинами і лесами. Єдина різниця, що у Східному Опіллі присутні “дністрові рінища”, що тягнуться 12-кілометровою смугою вздовж лівого берега Дністра (рис. 1).

Подністря. У межах подільського сточища Дністра С. Рудницький виокремлює також геоморфологічний регіон під назвою Подністря, яке простягається різної ширини смугою з північного заходу на південний схід лівим берегом Дністра, а русло є південною межею цього регіону. Північна межа ламаною лінією проходить від Роздолу попри Берездівці, Гранки, Ляшки, Бориничі, Голдовичі, Дев'ятники, Баківці, Стрілиська, Любшу, Підкамінь, Рогатин, Пуків, Липиці, Свистільники (з 1964 р. - с. Світанок - Я. К.), Гнильче, Горожанку до гирла Золотої Липи. За морфометричними показниками цей регіон від Опілля і Поділля відділяється плавним уступом, який на 50 м і більше підноситься понад горбами Подністря.

Подністря, як більшість інших природних регіонів Поділля, поділене притоками Дністра на межирічні горбовинні смуги, розміщені між долинами Бібрки, Свіржа, Гнилої Липи, Нараївки, Бібелки, Гнилого Потоку, Горожанки і Золотої Липи.

Власне Галищьке Поділля (за С. Рудницьким) обмежене 3 півдня долиною Дністра, від заходу - східним Опіллям, від півночі - вододілом, на сході долиною Збруча. "Морфографічна характеристика Поділля видавала б ся на перший погляд дуже проста. Бачимо перед собою плоску, майже зовсім рівну, полого схвильовану плиту з річковими долинами переважно полуденникового напряму” (Рудницький, 1913, с. 123). Загалом С. Рудницький погоджується 3 В. Тессейром, що горбовинний вал Товтрів (Медоборів) є дуже добрим критерієм поділу власне Поділля на західну і східну частини. Цьому сприяє його довжина, велика виразність у терені і значна висота.

Поділу височини сприяють також меридіональні долини Стрипи, Джурина, Серету, Нічлави і Збруча. “Так важливий для розчленування і поділу вал Товтрів (за В. Тессейром) перетинає напрям меридіональних долин ускісно i вони, оскільки його переходять, то роблять це поперечними проломовими долинами" 
Я. Кравчук, Ю. Зінько. Вивчення Степаном Рудницьким..

12

(Рудницький, 1913, с. 126).

За цим поділом на Поділлі розрізняють п’ять морфологічних смуг: дві вузькі горбовинні і три ширші височинні. Від заходу на схід виокремлено: високорівню зборівсько-чортківську, вал теребовлянсько-мельницький, високорівню тернопільсько-гусятинську, вал Товтрів-Медоборів і високорівню Східного Поділля (Рудницький, 1913, с. 269-270). Подільське сточище Дністра виринуло 3 моря під кінець міоценської доби. Міоценське море відступало на схід південний схід і тодішня суша утворилася широчезною смугою довкола дуги Карпат. Первісне консеквентне відводнення сарматського Підкарпаття було промінясте, і один з тих радіальних від Карпат потоків, мабуть, став прабатьком нинішнього Дністра.

Долину Дністра на Подністрі, Опіллі та Поділлі С. Рудницький аналізує детально, виокремлюючи для цього один розділ. Окрім того, значна частина монографії присвячена детальній характеристиці великих і порівняно малих долин Свіржа, Гнилої Липи, Золотої Липи, Коропця, Стрипи, Серета та інших.

В окремому розділі подано характеристику Головного Європейського вододілу в межах Опілля і Поділля. Гологірсько-Кременецька частина вододілу внаслідок тектонічних піднять спричинила (на думку С. Рудницького) також нинішній нахил Подільської височини до південного сходу - сходу, оскільки абразійна міоценська поверхня мала ще західний нахил. На Північному Поділлі до цього нахилу причетні дві плоскі антикліналі: перемишлянсько-чернелицька (Бердо-Нароль) в міоцені і гологірсько-кременецька по сарматі.

Будова покривних відкладів Поділля (старі рінища) та їх генетично-вікова інтерпретащія. Власне С. Рудницький вперше описав старі рінища (з присутнім карпатським матеріалом) Дністра на Подністрі, Опіллі та Поділлі. “Найдальше на північний захід .... на лівім березі Дністра зустрічаємо ділювіальні рінища біля Берездівців і в присілку Кути ... на висоті 290-300 м виступають тут рінища переважно $з$ місцевого треторяду, однак серед них я помітив кілька куснів чорного і жовтого роговика 3 олігоценських менілітових карпатських верств. В наплавнім стіжку Стрия і в руслі Дністра, що віддалені ледве кілька кілометрів від цього місця, таких ріняків дуже багато, однак малі ріняки лежать близько 50 м вище, вкриті верствованою ділювіальною глиною і лесом" (Рудницький, 1913, c. 245).

Автор детально описує поширення карпатських рінищ на межиріччях Лімниці-Лукви-Бистриці (правобережжя Дністра), тобто у правдоподібних місцях, на відміну від тих, що на лівому березі Дністра трапляються на значній висоті над рівнем ріки і на значній віддалі від русла. Виходи старих рінищ С. Рудницький описує поблизу с. Бовшіва північніше висоти 295 м. Переважають менілітові роговики та пісковики. Доволі часто "старі рінища" трапляються на межиріччі Нараївки і Бібельки неподалік Більшівців, Кукільників, Загір'я. Поблизу Старих Скоморох вони вкривають височину з г. Червона (350 м). Віддаль від берега Дністра доходить понад 14 км (дві милі), ріняки лежать на висоті 140 м над дзеркалом води в Дністрі.

Найширшу на лівому березі смугу старі рінища 3 присутністю карпатського матеріалу займають на межиріччі Золотої Липи і Серету. В долині Золотої Липи найдалі на північ виходи старих ріняків знаходять південніше Завадівки, поблизу Гранітного, Лазарівки, Лядського, Бобрівник. 
Я. Кравчук, Ю. Зінько. Вивчення Степаном Рудницьким..

13

ISSN 2519-2620. Проблеми геоморфології і палеогеографії..2019. Вип. 1 (9), 3-20

У долині Коропця С. Рудницький описує старі рінища неподалік Монастириськ, між Дубенками і Велесневом на висоті 350-360 м, поблизу Коропця - на висоті 393 м. Відносні висоти над руслом Дністра становлять 183200 м. Доволі далеко на північ від Дністра трапляються старі рінища в долинах Бариша, Стрипи, Джурина, Серету і Нічлави.

Після детального аналізу старих рінищ С. Рудницький зачислює їх до найстаріших нижньоплейстоценових і верхньопліоценових відкладів. Від них виразно відрізняються молодші четвертинні відклади, розміщені значно нижче приблизно за 50 м над нинішнім руслом рік. Ці рінища на території подільського сточища Дністра представлені тільки місцевим матеріалом.

Між долинами Коропця і Бариша С. Рудницький старі рінища описує неподалік Новосілки Коропецької на висотах до 380 м. Вони залягають між товщею глин (до 10 м) потужністю 4 м. Окрім карпатського матеріалу, М. Ломніцький простежував тут ріняки крейди девонських доломітів і пісковиків (Рудницький, 1913, с. 250). Такі ж рінища він описує на вузькій височинній смузі між Дністром і Баришем в околицях Порохової, які представлені доволі грубим матеріалом з карпатських пісковиків, жовтих і чорних менілітових роговиків.

Таким матеріалом засипана височина між Баришем і Стрипою на абсолютних висотах близько 400 м. "Зустрічав я сліди цих рінищ по дорозі зі Стінки до Золотого Потоку, коло Сновидова і над Возиловим та Унижем... коло Наваля i понижче, де лежать їх величезні маси... більшаюча до полудня перевага без сумніву карпатського пісківцевого матеріалу” (Рудницький, 1913, с. 250).

На думку С. Рудницького, найдалі на північ у долині Стрипи дністрові рінища є поблизу Звенигорода, де залягають під глиною і їхній розріз подібний до Лядського в долині Золотої Липи.

Між долинами Стрипи і Джурина старі дністрові рінища зосереджені у вузькій смузі вздовж Дністра поблизу с. Хмелева на висоті 350 м, а також уздовж потоку Кирниці за с. Дорогочівкою на висоті 330 м (посилання на карту Ф. Бєняша).

Найпотужніші розрізи з карпатським матеріалом описані С. Рудницьким у Дзвинячі та його околицях. "Найбільша відкривка старих рінищ $є$ коло горба Кадовб $(284$ м)... Перевага $є$ по стороні карпатських пісковиків і жовтих роговиків, крім цього $є$ рінячки яспісу, халькедону, білого кварцу, синявих і чорних кременів та гарно обточених рінячків девонського пісковика" (Рудницький, 1913, с. 252).

На межиріччі Серету і Збруча старі рінища представлені широкою смугою на лівому березі Дністра. У долині Серету вони відслонюються поблизу с. Олексинці, у долині Нічлави - неподалік с. Висічка. Поблизу сіл Олексинців і Більча карпатський матеріал залягає на абсолютних висотах близько 300 м і представлений кременями, яспісами, карпатськими менілітами.

Старі ділювіальні рінища (нижній плейстоцен - верхній пліоцен) подільського сточища Дністра С. Рудницький пов'язує зі смугою підкарпатських рінищ. "Я маю непохитне пересвідчення, що смуга староділювіальних рінищ наддністрянських $є$ дуже на значнім просторі у безпосередньому зв'язку зі смугою підкарпатських староділювіальних рінищ, творячи їх найбільш зовнішню частину” (Рудницький, 1913, С. 254).

У тридцятих роках минулого століття $\mathrm{B}$. Тессейр виокремив на 
Я. Кравчук, Ю. Зінько. Вивчення Степаном Рудницьким..

14

ISSN 2519-2620. Проблеми геоморфології і палеогеографії...2019. Вип. 1 (9), 3-20

підкарпатських межиріччях дві денудаційно-акумулятивні поверхні, одну з яких назвав поверхнею Лоєвої, а іншу - поверхнею найвищою, вік яких верхній пліоцен-нижній плейстоцен. Раніше їх описували Ф. Бєняш на карті ТисмяницяТлумач (і то дуже не докладно - С. Рудницький) і М. Ломніцький на карті Коломия (дуже сумлінно - C. Рудницький).

Отже, до найстаріших плейстоценових відкладів 3 карпатським матеріалом власне Поділля С. Рудницький зачислює смугу шириною понад 20 км, північна межа котрої проходить через Монастириська, Бучач, Бураківку, Кривче, а південна - місцями перетинає нинішню течію Дністра.

До другої групи ділювіальних (плейстоценових) відкладів С. Рудницький зачислює піски, які переважно тісно пов'язані з рінищами. “Всюди, де старі дністрові рінища зустрічаються у первіснім неперелавленім стані, виступають у сполуці з ними верстви піску іменно у верхові відкривок” (Рудницький, 1913, с. 257). 3 посиланням на В. Тессейра розрізняють два роди пісків: летючі та піски у споді мамутової глини. Щодо віку пісків, то деякі верстви зачислюють до пліоцену. За способом утворення пісків, які підстеляють мамутову глину, їх вважають річковим утворенням. "Третю групу плейстоценових утворень Поділля творять глини і споріднені з ними елювіальні осади ... мій погляд щодо поділу глин співпадає 3 поглядами $\mathrm{B}$. Тессейра. В. Тессейр не приймає поділу на височинну і збочеву глину, а розрізняс типовий лес еолічного походження від тонко верствованої спідньої глини, котру зове попеличною... Стратиграфічний перехід від попеличної глини до лесу є дуже повільний” (Рудницький, 1913, c. 257$)$.

Після детального розгляду літературних джерел і власних досліджень Поділля С. Рудницький доходить висновку, що всюди на старих рінищах, пісках і елювіальнтх глинах лежить “еолічний лес" (Рудницький, 1913, с. 262), що вкриває не лише схили долин, а й межирічні поверхні. 3 посиланням на дослідження М. Ломніцького (Рудницький, 1913, с. 263) зроблена спроба визначити вік ділювіальних відкладів Поділля. Яспісові рінища і піски зачислені до нижнього пліоцену, а, можливо, й до рівновікового верхнього пліоцену Західної Європи. У час відкладання рінищ і пісків панував арктичний клімат із середньорічною температурою нижче $-4{ }^{\circ} \mathrm{C}$. Нижню частину середнього плейстоцену репрезентує уверствована глина (синя, післяльодовикова), сформована у часи панування арктичного пустельного клімату із середньою температурою $+4{ }^{\circ} \mathrm{C}$.

Верхня частина середнього плейстоцену представлена жовтою неуверствованою глиною-лесом, утвореною у степовій зоні 3 холодним сухим кліматом, близьким до сучасного північно-східного європейського. 3 верхнім плейстоценом пов'язують формування травертинів. Як зазначає С. Рудницький, їхнє утворення продовжувалося на початку староалювіального часу (голоцен) у долині Дністра та його подільських приток і продовжується досі поблизу джерел.

\section{3. Проблематика історії розвитку рельєфу Поділля}

Проблеми формування рельєфу Поділля С. Рудницький розпочинає розглядати 3 доволі детального аналізу наукових праць Е. Дуніковського, В. Тессейра, М. Ломніцького, Е. Тіце, В. Гільбера, В. Уліга, Г. Величка. Здебільшого ці дослідження пов'язані з геологічним зніманням території Поділля віденськими і галицькими геологами. Передусім під час вивчення регіону 
Я. Кравчук, Ю. Зінько. Вивчення Степаном Рудницьким...

15

постало питання, “чому Дністер, маючи в підкарпатській геосинкліналі вигідну дорогу на південний схід, минув іiі і врізався глибоким яром у Подільську височину?" (Рудницький, 1913, с. 268).

“'3 цим питанням в’яжеться безпосередньо квестія як витворився яр Дністра, як повстала водяна і долинна сіть його височинних приток, ... повстанням Подільської височини і ії морфології, ... творби виразно в терені зарисованих границь Поділля головно його північного рубця. Через ціле Поділля йде майже повсюдно явище асиметрії, що також творить важливий проблем його морфології. Крім цих проблем є багато дрібніших: зв'язок землетрусів 3 найновішими тектонічними рухами Поділля, проблема суходолів, красові явища, степово-пустинні форми поземелля як вислід колишньої дефляції і насипової діяльності вітру, відносини Дністра до Вісли, Дніпра, Бугу, Пруту і т. д.” (Рудницький, 1913, с. 268-269).

Причому С. Рудницький відкинув одну із тез В. Тессейра про те, що опільські скибові складки (Пн3х - ПдСх) існували протягом міоцену. Він вважав, якщо б вони існували на поверхні молодої сарматської суші, то тільки маленька ії частина могла б бути відводнена на схід, північний схід і північ. Натомість цілий простір на південному сході мусів би дістати північно-західне відводнення, а Дністер своєю течією був би аналогом Богові (Південний Буг), тобто не мав би карпатського і підкарпатського сточищ.

3 відступом сарматського моря розпочалися підняття ГологороКременецького пасма (за В. Тессейром), яке обумовило нинішній південносхідний нахил Поділля. Проти сарматського віку цього пасма виступили I. Смолєнський і С. Павловський, а С. Рудницький обгрунтував пліоценовий вік цього пасма і формування сточища Дністра.

"Які відносини панували у пліоценських часах на Поділлю, на те не маємо ніяких достовірних і певних вказівок, ... бо не знаємо до тепер 3 нашого простору ніяких безсумнівних пліоценських відложень" (Рудницький, 1913, c. 268-269). Знахідка Вольфом у староалювіальних терасах поблизу Чорткова понтійських скам'янілостей дала В. Гільберту можливість припустити пліоценовий вік височинної глини Поділля. Загалом С. Рудницький назвав це припущення правдоподібним, “бо ніхто не стане перечити, що від початку пліоцену аж по нинішний день наша область $є$ сушею, та найстаріші елювії мусять своїми початками сягати пліоцена. Приклад червона елювіальна глина в Доброводах представляє певні аналогії до terra rossa південно-європейських вапнякових областей і вказує на тепліший клімат пліоцену” (Рудницький, 1913, c. 274).

Аналізуючи підкарпатське сточище Дністра, С. Рудницький вважає, що одинокою пам'яткою з пліоцену належало би визнавати тодішній напрям долини Дністра. Пліоценова ерозія не могла бути тоді значною. Це також стосується і подільського сточища Дністра, де у пліоцені чітко визначився тільки напрям головної ріки. Він плив рівниною до свого гирла в понтійсько-каспійському басейні, не зустрічаючи жодних перепон. Найімовірніше, на той час він мав меандри, які не мали нічого спільного з сучасними. Пліоценові меандри Дністра, молодої консеквентної ріки, були вільними, або блукаючими, на відміну від сучасних, переважно врізаних.

Пліоценовий Дністер був рікою рівнинного типу. Свої верхів'я він мав на 
Я. Кравчук, Ю. Зінько. Вивчення Степаном Рудницьким..

16

ISSN 2519-2620. Проблеми геоморфології і палеогеографії...2019. Вип. 1 (9), 3-20

вирівняній Підбескидській поверхні (нижня денудаційна поверхня С. Рудницького, Погурська - Л. Савицького, Суббескидська М. Клімашевського, П. Цися). Зокрема, вік Підбескидської поверхні М. Клімашевський вважає пліоценовим, П. Цись - нижньопліоценовим, I. Гофштейн - верхньопліоценовим.

Досліджуючи північний край Поділля, зокрема Гологоро-Кременецьке пасмо, С. Рудницький категорично заперечив його куестове походження. Аргументував це відсутністю типового моноклінального залягання порід, чергування твердих і менш стійких порід. Не погодився С. Рудницький і з визначенням віку пасма: бо годі було припустити, “щоб у пліоцені зачав творитися північний поріг Поділля, а його творення потрібно пересунути на дещо пізніший час” (Рудницький, 1913, c. 280$)$.

Важливі і найправдоподібніші варіанти формування річкової мережі басейну Дністра у пліоцені та плейстоцені також належать С. Рудницькому. Він вніс істотні зміни у розвиток річкової мережі Дністра і його приток у пліоцені та нижньому плейстоцені, зокрема напряму течій лівих приток і перехоплення їхніх верхів 'їв притоками Західного Бугу.

Північно-західний - південно-східний напрям течії Дністра остаточно сформувався у пліоцені i тривав протягом плейстоцену. Як засвідчує С. Рудницький, більші лівобережні притоки Дністра не мають чітко південного напряму. У їхніх верхів'ях і пригирлових ділянках домінує північно-західний і південно-східний напрям. Навіть Збруч типово зраджує свій відхід до південносхідного напряму.

Питання походження віку і способу утворення старих подільських рінищ С. Рудницький вважав найдискусійнішим. Він особисто підтримав версію Ф. Бєняша, що старі рінища містять матеріал карпатського походження. Не погодився С. Рудницький з тим, що на аркушах карт Тисмениці і Монастириська наявний тільки карпатський матеріал. 3 цього приводу він зазначає, що змішаний карпатський і подільський матеріал знаходиться ще далеко на захід від згаданих теренів, зокрема поблизу населених пунктів Скоморохи, Дитятин, Товстобаби, Миловане. Чим далі на схід, тим відсоток подільського матеріалу збільшується, а карпатський ще домінує неподалік околиць Дзвиняча, Шупарки, Михайлівки.

Вік старих рінищ С. Рудницький вважає передльодовиковим. Нагадаємо, що він дотримувався поділу льодовикових періодів німецькими дослідниками, які у ділювії (плейстоцені) виокремлювали сім віків. На їхній основі С. Рудницький вирізняв три віки: староділювіальний, що відповідає першій перигляціальній, першій льодовиковій і першій післяльодовиковій добам; другий льодовиковий вік, що відповідає другій льодовиковій добі; молододілювіальний вік, що відповідає другій міжльодовиковій добі, третій льодовиковій і післяльодовиковій.

Початок інтенсивних піднять Поділля автор зачислює до кінця другої льодовикової доби, яка тривала протягом молододілювіального віку. До початку цих піднять на Поділлі були умови, аналогічні пліоцену. Тобто староділювіальний (нижньоплейстоценовий) Дністер був “низинною рікою і його долина була плитка i широка, виповнена рінню, принесеною карпатськими $\mathrm{i}$ подільськими притоками. ІІї врізування в рівнину не могло перевищити 10-20 м, натомість ширина місцями перевищувала 20 км. Дністер у цих часах обмежував 
Я. Кравчук, Ю. Зінько. Вивчення Степаном Рудницьким..

17

ISSN 2519-2620. Проблеми геоморфології і палеогеографії...2019. Вип. 1 (9), 3-20

свою діяльність на пересування своїх меандрів по широкім дні своєї долини. 3 трудом переміщував по своєму дну маси ріні, яку йому щораз у більших кількостях доставляли карпатські притоки в міру того як наступило чергове підняття Карпат і підвищувалася інтенсивність ерозії” (Рудницький, 1913, с. 296).

Заслуговує на увагу ще один висновок С. Рудницького про те, що карпатські рінища наддністрянські не можуть бути старшими, ніж підкарпатська вирівняна поверхня, а, найімовірніше, молодші. Це згодом підтвердив Г. Тессейр 1933 року, виокремлюючи у межах Передкарпаття дві денудаційні поверхні: Лоєвої і найстаршу, які згодом назвали денудаційно-акумулятивними.

Висновки. Морфологічні, генетичні та еволюційні проблеми розвитку рельєфу Західного Поділля і Розточчя, розглянуті у праці Степана Рудницького “Знадоби до морфології подільського сточища Дністра”, не втрачають своєї актуальності до нашого часу. На його доробках грунтуються сучасні узагальнення геоморфологічної регіоналізації Західного Поділля (Цись, 1962; Кравчук і Зінько, 1997, 1997а; Палієнко та ін., 2007; Кравчук і Зінько, 2018; Гнатюк, 1999, 2000), дослідження морфологічної структури окремих регіонів та еволюційно-генетичні інтерпретації розвитку подільської частини Дністра та його приток (Гнатюк, 1999, 2000).

Застосування сучасних підходів (морфолітологічного, морфотектонічного) та інструментаріїв (ГІС-технології) (Чупило (Байрак), 2002)) у дослідженні рельєфу і покривних відкладів Подільської височини та Розточчя в межах басейну Дністра дає змогу отримати нові результати, пов'язані з проблематикою морфогенетичної інтерпретації будови рельєфу та етапності його розвитку.

\section{СПИСОК ВИКОРИСТАНОЇ ЛІТЕРАТУРИ}

Геоморфологічна карта. Масштаб 1:800 000 / Кравчук Я. С., Зінько Ю. В. // Навчальний атлас України. - Київ : Картографія, 1997. - С. 10.

Геоморфологічне районування. Масштаб 1:800 000 / Кравчук Я. С., Зінько Ю. В. // Навчальний атлас України. - Київ : Картографія, 1997а. - С. 10.

Геоморфологічне районування України. Карта масштабу $1: 5000000$ / Палієнко В. П. та ін. - Національний атлас України. - Київ : Картографія, 2007. - C. 162.

Гнатюк Р. Геоморфологія. - Карта масштабу 1 : 1500000 / Р. Гнатюк. Навчально-краєзнавчий атлас Львівської області. - Львів: ВНТЛ, 1999. C. 7.

Гнатюк Р. Геоморфологія (карта масштабу $1: 1000$ 000) / Р. Гнатюк. Навчально-краєзнавчий атлас Тернопільської області. - Львів: ВНТЛ, 2000. - C. 7.

Зінько Ю. Комплексний морфологічний аналіз рельєфу Подільського регіону в дослідженнях Степана Рудницького / Ю. Зінько // Акад. С. Рудницький основоположник української географічної науки. - Відп. ред. проф. О. Шаблій. - Львів: ЛДУ ім. Івана Франка, 1994. - С. 93-100.

Кравчук Я. 3 історії геоморфологічних досліджень в Україні / Я. Кравчук // 3 історії геоморфологічних досліджень в Україні : Мат. наук. конф. присв. 95річчю проф. В. Кубійовича. - Тернопіль, 1995. - С.82-85.

Кравчук Я. Академік Степан Рудницький - перший український геоморфолог / 
Я. Кравчук, Ю. Зінько. Вивчення Степаном Рудницьким...

18

ISSN 2519-2620. Проблеми геоморфології і палеогеографії...2019. Вип. 1 (9), 3-20

Я. Кравчук // Історія української географії. - Вип. 36. - Тернопіль, 2017. C. $22-32$.

Кравчук Я. С. Рельєф Львівської області. Додаток: Геоморфологічна карта Львівської області / Я. Кравчук, Ю. Зінько // Львівська область: природні умови та ресурси: Монографія / [За ред. М. М. Назарука]. - Львів: Вид. Старого Лева, 2018. - С. 55-85.

Рудницький С. Знадоби до морфології карпатського сточища Дністра / С. Рудницький // Зб.матем.-природ.-лік. секції НТШ. - 1905. - Т.Х. - 85 с.

Рудницький С. Знадоби до морфології підкарпатського сточища Дністра / С. Рудницький // Зб.матем.-природ.-лік. секції НТШ. - 1907. - Т.ХІ. - 79 с.

Рудницький С. Знадоби до морфології подільського сточища Дністра / С. Рудницький // Зб. Матем.-природ.-секції НТШ. - 1913. - Т.XV - 310 с.

Рудницький С. Морфологічні краї Східної Свропи / С. Рудницький // Sbornik reměpisnych praci venovanych prof. V. Svamberowi. - Praha, 1926.

Чупило (Байрак) Г. Морфологічна структура рельєфу Поділля Степана Рудницького і за даними сучасних аерознімань / Галина Чупило (Байрак) // Матеріали II Всеукраїнського семінару "Регіональне географічне краєзнавство: теорія і практика". - Тернопіль, 2002. - С. 54-56.

Шаблій О. Академік Степан Рудницький - фундатор української географії / О. Шаблій // Редак.-вид. відділ ЛДУ ім. І. Франка.- Львів- Мюнхен, 1993. $223 \mathrm{c}$.

Цись П. М. Геоморфологія УРСР / П. М. Цись. - Львів: Львівський університет, 1962. $-244 \mathrm{c}$.

\section{REFERENCES}

Kravchuk, Y. S., Zin'ko, Y. V. (1997) Geomorfologichna karta [Geomorphological map]. 1:800 000. In Navchalnyi atlas Ukrainy. Kyiv : Kartografiya. P. 10. (In Ukrainian)

Kravchuk, Y.S., Zin'ko, Y.V. (1997a) Geomorfologichne rayonuvannia [Geomorphological zoning]. 1:800 000. In Navchalnyi atlas Ukrainy. Kyiv : Kartografiya. P. 10. (In Ukrainian)

Paliyenko, V. P. et all (2007). Geomorfologichne rayonuvannia Ukrainy [Geomorphological zoning of Ukraine. Scale 1:5 000 000]. In Navchalnyi atlas Ukrainy. Kyiv : Kartografiya. P. 162. (In Ukrainian)

Hnatiuk, R. (1999). Geomorfologiya. Karta masshtabu 1:1 500000 [Geomorphology. Scale map 1:1500 000]. In Navchalno-krayeznavchyi atlas Lvivskoyi oblasti. Lviv : VNTL. P. 7. (In Ukrainian)

Hnatiuk, R. (2000). Geomorfologiya (Karta masshtabu 1:1 000 000) [Geomorphology. Scale map 1:1 000 000]. In Navchalno-krayeznavchyi atlas Ternopilskoyi oblasti. Lviv : VNTL. P. 7. (In Ukrainian

Zin'ko, Y. V. (1994). Kompleksnyi morfologichnyi analiz relief Podilskogo regionu v doslidzenniach Stepana Rudnytskogo [Complex morphological analysis of the relief of the Podilskyi region in the studies of Stepan Rudnitskyi]. In Akad. S. Rudnytskyi - osnovopoloznyk ukrainskoyi geografichnoyi nauky. Widp. red. O. Shabliy. Lviv : LDU im. Ivana Franka, 93-100. (In Ukrainian)

Kravchuk, Y. S. (1995). Z historii geomorfologichnych doslidzen' v Ukraini [From the 
Я. Кравчук, Ю. Зінько. Вивчення Степаном Рудницьким...

19

ISSN 2519-2620. Проблеми геоморфології і палеогеографії...2019. Вип. 1 (9), 3-20

history of geomorphological studies in Ukraine]. In $Z$ historii geomorfologichnych doslidzen' v Ukraini : Mat. nauk. konf. prysv. 95-richchiu prof. V. Kubiyovycha. Ternopil, 82-85. (In Ukrainian)

Kravchuk, Y.S. (2017). Akademik Stepan Rudnytskyi - pershyi ukrainskiy geomorfolog [Academician Stepan Rudnitskyi is the first Ukrainian geomorphologist]. In Historiya ukrainskoyi geografii, 36, 22-32. (In Ukrainian)

Kravchuk, Y. S., Zin'ko, Y. V. (2018). Relief Lvivskoyi oblasti. Dodatok: Geomorfologichna karta Lvivskoyi oblasti [Relief of Lviv region. Appendix: Geomorphological map of Lviv region]. In Lvivska oblast: pryrodni umovy ta resursy: Monografiya. Nazaruk M. M. (Ed.). Lviv : Vyd. Starogo Leva, 55-85. (In Ukrainian).

Rudnytskyi, S. (1905). Znadoby do morfologiyi Karpatskogo stochyshcha Dnistra [Knowledge of the morphology of the Carpathian Dniester basin]. In Zb. Matem.pryrod.-lik. Sekciyi NTSh, X. 85. (In Polish).

Rudnytskyi, S. (1907). Znadoby do morfologiyi Pidkarpatskogo stochyshcha Dnistra [Knowledge of the morphology of the Subcarpathian Dniester basin]. In $Z b$. Matem.-pryrod.-lik. Sekciyi NTSh., XI, 79. (In Polish).

Rudnytskyi，S. (1913) Znadoby do morfologiyi Podilskogo stochyshcha Dnistra [Knowledge of the morphology of the Podilskyi Dniester basin]. In Zb. Matem.pryrod.lik. Sekciyi NTSh,XV, 310. (In Polish)

Chupylo (Bayrak), G. (2002). Morfologichna struktura rel'jefu Podillja Stepana Rudnyc'kogo i za danymy suchasnyh aerozniman' [The morphological structure of the Podillya relief of Stepan Rudnitsky and according to modern aerial sensing]. In "Regional'ne geografichne krajeznavstvo: teorija i praktyka": Materialy II Vseukrai'ns'kogo seminaru, Ternopil', 54-56. (In Ukrainian).

Shabliy, O. (1993). Akademik Stepan Rudnytskyi - fundator ukrainskoyi geografiyi [Academician Stepan Rudnitsky is the sponsor of Ukrainian geography]. Redak.vyd. Viddil LDU im. I. Franka. Lviv-Munchen, 223. (In Ukrainian)

Tsys, P. M. (1962). Geomorfologiya URSR [Geomorphology of the URSR]. Lviv : Lvivskiy universytet, 244 (In Ukrainian). 


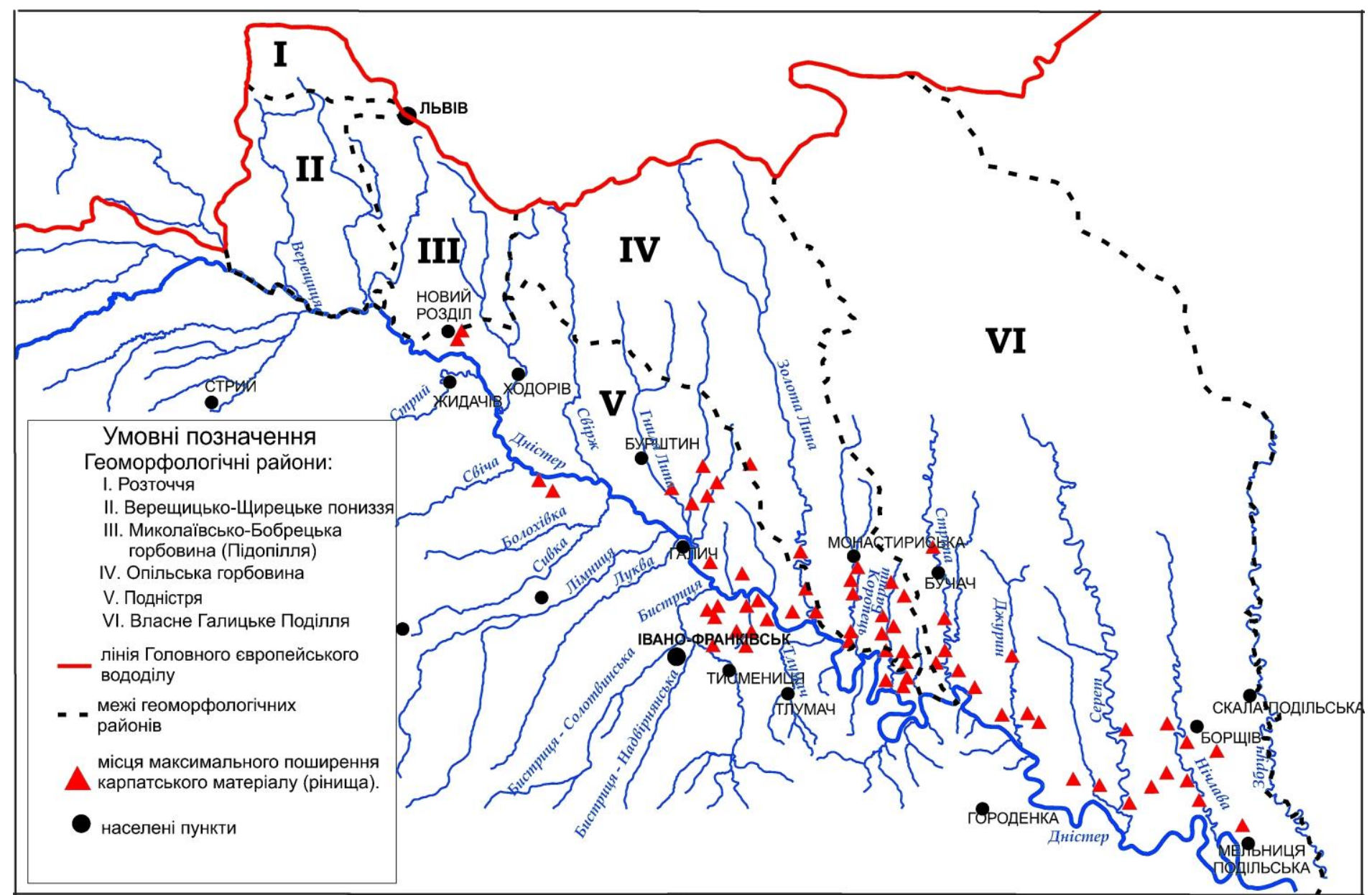

Рис. 1. Схема геоморфологічних районів подільського басейну Дністра (за С. Рудницьким, 1913)

Fig. 1. Scheme of geomorphological regions of the Podilsky basin of the Dniester (according to S. Rudnitsky, 1913) 